\title{
Milligram per Gram per Minute
}

National Cancer Institute

\section{Source}

National Cancer Institute. Milligram per Gram per Minute. NCI Thesaurus. Code C73741.

A dose calculation unit expressed in milligram(s) per gram per period of time equal to sixty seconds. 